\title{
THE BOLOGNA PROCESS AND THE LISBON STRATEGY: COMMERCIALISATION OF HIGHER EDUCATION THROUGH THE BACK DOOR?*
}

\begin{abstract}
Sacha Garben**
Summary: The higher education sectors of European countries have been subjected to an unprecedented amount of reforms over the past decade. Much of these changes are the consequence of the Bologna Process, which introduces a common Bachelor-Master-Doctorate system in the participating countries, with a view to increasing the employability of the European citizen and the international competitiveness of Europe as a whole. Apart from the Bologna Process, the important EU policy project called the Lisbon Strategy clearly affects higher education policy, as its goal is to establish the world's most competitive knowledge economy. 'Lisbon' and 'Bologna' increasingly converge, particularly via the Open Method of Coordination, which is not surprising considering that they are both part of the same momentum. This momentum seems to regard education almost exclusively as an economic commodity, and it could therefore be argued that both policy projects contribute to a commercialisation of higher education. The desirability of this development is questionable, and the fact that both Bologna and Lisbon suffer from serious democratic defects indicates that much needed public-wide discussions are lacking.
\end{abstract}

\section{Introduction}

Education serves to pass on society's values to the children of the nation and is employed by the state to make 'good citizens'. ${ }^{1}$ The choice of the values that a society decides to transmit to its future members is intrinsically connected to national identity. Therefore, 'deeply rooted in local, regional and national culture, education takes different forms in each country reflecting the different expectations of our societies'. ${ }^{2}$

\footnotetext{
This paper is largely based on the PhD research of the author, forthcoming as S Garben, EU Higher Education Law. The Bologna Process and Harmonization by Stealth (Kluwer Law International, The Hague 2011).

** Administrator, Research and Documentation Centre, Court of Justice of the EU. All views expressed in this contribution are strictly personal.

1 See D Ravitch \& J Viteritti, Making Good Citizens, Education and Civil Society (Yale University Press, New Haven 2001).

2 As stated by M Marin, member of the European Commission, in a European Parliament debate on encouraging teacher mobility. Debates of the European Parliament (24 October 1986) OJ Annex No 2-344/275, 281. See also J Handoll, 'Foreign Teachers and Public Education' in B de Witte (ed), European Community Law of Education (Nomos Verlagsgesellschaft, Baden-Baden 1989) 31, 31.
} 
Going to the core of state sovereignty, education is a firmly established competence of the nation state. ${ }^{3}$ As Leuze and others note, ${ }^{4}$ education has become a 'normative good'5 of the modern state, and it is this state that prominently decides on the structural set-up of the education systems, arranges the financing of education for its citizens and is held accountable for the achievements, as well as the failures. It is natural for the state to defend its position as the decider, internally as well as externally. In an EU context, the foregoing finds reflection in what is now art 165 TFEU. This provision, introduced by the Maastricht Treaty, does acknowledge a role for the EU in educational matters, but limits this role to a complementary and subsidiary one to that of the Member States. The national educational autonomy paradigm, laid down in the first paragraph, is not even the most restrictive aspect of the provision. The prohibition of harmonisation enshrined in paragraph 4 constitutes the first explicit negative limitation of competence in the history of European law, which the Maastricht Treaty introduced together with similar prohibitions in the fields of culture and health.

Art 126 of the EC Treaty (now art 165 TFEU) can be seen as an attempt of the Member States to draw clear lines in the sand, or to 'clip the wings' of the EC. ${ }^{6}$ In the preceding years, the Community had managed to create law and policy in the area of education, facilitated in no small manner by extensive interpretations of the Treaty by the European Court of Justice (ECJ). Claims of students arguing unfair treatment in other Member States met with an understanding ECJ, which granted them the right to study abroad and - in principle - to receive the same treatment as nationals, even though this was not explicitly provided by the Treaty. The Court's extensive interpretation of what constituted 'vocational training' also allowed the European Commission to launch its ambitious ERASMUS programme, which to date has allowed over 1.5 million students to benefit from a period of study in a Member State other than

\footnotetext{
3 E Young, 'Protecting Member State Autonomy in the European Union: Some Cautionary Tales From American Federalism' (2002) 77 New York University Law Review, Vol. 77, 2002, 1670-1677.

4 K Leuze and others, 'Transformations of the State' (2008) TranState Working Paper, Bremen No 72/2008 1 .

5 A Hurrelmann and others, The Golden-Age Nation State and its Transformation: A Framework for Analysis' in A Hurrelmann, S Leibfried, K Martens, \& P Mayer (eds), Transforming the Golden-Age Nation State (Palgrave Macmillan, Houndmills, Basingstoke 2007) 3.

6 See J Lonbay, 'Reflections on Education and Culture in EC Law' in: R Craufurd Smith (ed), Culture and European Union Law (OUP 2004) 244. See also M Dougan, 'Fees, Grants, Loans and Dole Cheques: Who Covers the Cost of Migrant Education within the EU?' (2005) 32 CML Rev 949; J Shaw, 'From the Margins to the Centre: Education and Training Law and Policy' in P Craig and G de Búrca (eds), The Evolution of EU Law (OUP 1999); and G. Gori, Towards an EU Right to Education, (Kluwer Law International, The Hague 2001).
} 
their own. ${ }^{7}$ Although an education dimension was never absent from the Treaty, for even its oldest form contained provisions enabling the adoption of measures for the mutual recognition of diplomas ${ }^{8}$ and in the area of vocational training, ${ }^{9}$ these developments are generally regarded to have taken place in the absence of a real Treaty base, and are therefore often criticised. Murphy, for example, states that:

the fuzzy, blurred, and covert history of education policy in Europe does not contribute much to a sense of optimism regarding the strengthening of European democratic legitimacy, a key and indispensable component of any effective post-national form of citizenship. ${ }^{10}$

Art 126 of the EC Treaty (now art 165 TFEU) codified the existing practice, thereby providing the Community with explicit legitimacy for the de facto policy that had come into existence, while at the same time establishing clearly that that was as far as it should go. ${ }^{11}$

\section{The European Court of Justice and national educational autonomy}

Nevertheless, it appears that the ECJ has not seized its judicial activism in this area since Maastricht, as it has continued to hand down controversial judgments, qualifying 'privately funded' education as a 'service' within the meaning of the Treaty, ${ }^{12}$ demanding equal treatment of foreign EU students even with regard to maintenance grants ${ }^{13}$ and condemning legislation aimed at combating the flooding of faculties by foreign students that seek to escape national numerous clauses regimes. ${ }^{14}$ In this light, it is not all that surprising to find national politicians on occasion pitted against the ECJ. The Court has made it abundantly clear that edu-

7 Case 242/87 Commission v Council (ERASMUS) [1989] ECR 1425. On the ERASMUS case, see Lenaerts, 'ERASMUS: Legal Basis and Implementation” in de Witte (n 2). For facts and figures on the ERASMUS exchange programme, see European Commission, The History of European Cooperation in Education and Training: An Example of Europe in the Making (Office for Official Publications of the European Communities, Luxembourg 2006).

$8 \quad$ Art 57 EEC (now art $47 \mathrm{EC}$ ).

9 Art 128 EEC (now art 150 EC).

10 M Murphy, 'Covert Action? Education, Social Policy and Law in the European Union' (2003) 18 (5) Journal of Education Policy 560.

11 See M Verbruggen, 'Tussen Subsidiariteit en Harmonisatie: Een onderzoek naar de instrumenten voor het voeren van een Europees onderwijsbeleid' (PhD Thesis, Catholic University of Leuven, 2001) 15.

12 Case C-76/05 Schwarz and Gootjes-Schwarz v Finanzamt Bergisch Gladbach [2007] ECR I-6849.

13 Case C-209/03 The Queen, on the application of Dany Bidar $v$ London Borough of Ealing and Secretary of State for Education and Skills [2005] ECR I-2119.

14 Case C-147/03 Commission of the European Communities $v$ Republic of Austria [2005] ECR I-5969. See S Garben, 'Case C-73/08 Nicolas Bressol and Others, Celine Chaverot and Others $v$ Gouvernement de la Communauté française, Judgment of the Court (Grand Chamber) of 13 April 2010, nyr' (2010) 47 CML Rev 1493 - 1510. 
cation is not an area outside the scope of the Treaty, and that it can be deeply affected by the application of internal market freedoms as well as EU legislation. Even in 1974, the Court stated that:

although educational and training policy is not as such included in the spheres which the Treaty has entrusted to the Community Institutions, it does not follow that the exercise of powers transferred to the Community is in some way limited if it is of such a nature as to affect the measures taken in the execution of a policy such as that of education and training. ${ }^{15}$

Subsequently, the ECJ interpreted vocational training so as to include an element of 'general education' in its important Gravier judgment, ${ }^{16}$ which it further developed in the Blaizot case, ${ }^{17}$ clarifying that university education could also qualify as vocational training, as long as the course was intended to prepare the student for an occupation. As was mentioned above, this was a prelude to the Court's controversial ERASMUS judgment, in which it interpreted that same provision so as to provide for sufficient legal competence to support a far-reaching student exchange programme. ${ }^{18}$

Apart from the ECJ's extensive interpretation of EU competences, its consistent practice to apply the fundamental freedoms of the Treaty unrestrictedly in the area of education is of considerable consequence. Firstly, teachers, as they perform 'services of some economic value for and under the direction of another person' in return for which they receive remuneration, qualify as 'workers' within the meaning of art 45 TFEU (ex art 39 EC). ${ }^{19}$ The ECJ has confirmed in numerous cases that the teaching profession does not fall within the public service exception of art 45(4) TFEU (ex art 39(4) EC), even though teachers might have to take decisions as prescribed by national public law, such as awarding marks and deciding whether a pupil can move to a higher class. ${ }^{20}$ Secondly, the educational institution also derives rights from European law. ${ }^{21}$ Under certain conditions, the institution can qualify as a service provider within

\footnotetext{
15 Case 9/74 Donato Casagrande v Landeshauptstadt München [1974] ECR 773.

16 Case 293/83 Gravier [1985] ECR 593.

17 Case 24/86 Blaizot v. University of Liege [1988] ECR 379.

18 Case 242/87 Commission v. Council (Erasmus) [1989] ECR 1425.

19 Case 66/85 Lawrie-Blum v Land Baden-Wuertemberg [1986] ECR 2121. See on this topic Handoll (n 2) 31-50.

20 It does not matter whether it concerns a secondary school teacher, a foreign language assistant at a university, a university teacher or even a trainee teacher, in principle they are all entitled to benefit from the rights attached to worker status. See Cases C-4/91 Annegret Bleis v Ministère de l'Education Nationale [1991] ECR I-5627; C-33/88 Pilar Allué and Carmel Mary Coonan v Università degli studi di Venezia [1989] ECR 1591; and C-290/94, Commission v Greece [1996] ECR I-3285.

${ }^{21}$ See on this topic W Skouris, 'La Liberté d'établissement et de prestation de services en matière d'enseignement' in de Witte (n 2) 21-29.
} 
the meaning of art 56 TFEU (ex art 49 EC), and it also benefits from the freedom of establishment as provided by art 49 TFEU (ex art 43 EC). ${ }^{22}$ This allows foreign educational institutions to penetrate the 'education market' of other Member States, by offering courses, concluding cooperation agreements with national institutions, by opening subsidiaries and in many other ways. This might cause concerns about governmental control over the organisation, content and quality of the higher education offered on their territory, and potentially stands in tense relation with art 165(1) EC. Thirdly, students enjoy the right to freedom of movement and equal treatment, sometimes derived from their worker status, sometimes being children of workers, and sometimes simply by virtue of their studies preparing them to be a worker, strengthened by their European citizenship. This especially has proven to be a controversial matter. Member States are hesitant to accept the full equal treatment of students, especially those who are not economically active. It could be questioned whether foreign students should receive on an equal basis all the educational facilities, services and even grants made available by the host state to its nationals, without having contributed to the welfare system of that state.

To a certain extent, the approach of the Court is based on sound logic. After all, the EU has been endowed with a number of functional powers to achieve certain policy objectives, such as the creation of the common market and therein the free movement of persons, which may require changes in all kinds of sectors, including education. ${ }^{23}$ It is therefore nothing less than logical that many policy fields that were initially not intended to be EU business can be and have been affected in the slipstream of the implementation of these functional powers, even in the absence of explicit legal competence. ${ }^{24}$ It is, however, remarkable that the Court attaches so little value to the national autonomy principle as laid down in art 165(1) TFEU, even more so because it has done much to give legal significance to the second paragraph of that very same provision, in order to broaden the scope of EU influence. In the Jundt case, ${ }^{25}$ the ECJ condemned a German law denying a German national a tax concession for university teaching, because the teaching took place in another Member State. This was held to be a restriction of the freedom to provide services as laid down in art 56 TFEU (ex art $49 \mathrm{EC}$ ). In answering the question whether this restriction could be justified, the Court used the objectives of art 165(2) TFEU, in particular the promotion of teacher and student mobility, to reject the argument of the German Government

\footnotetext{
22 Case C-153/02 Valentina Neri v European School of Economics [2003] I-13555.

${ }^{23}$ B de Witte, 'Introduction' in de Witte (n 2) 10.

${ }^{24}$ B de Witte, The Scope of Community Powers in the Field of Education and Culture in the Light of Subsequent Practice' in R Bieber \& G Ress (eds), The Dynamics of EC-Law (Nomos Verlagsgesellschaft, Baden-Baden 1987) 236.

25 Case C-281/06 Jundt $v$ Finanzambt [2007] ECR I-0000.
} 
that the national legislation was justified by the promotion of teaching, research and development as an overriding reason in the public interest, while ignoring the first paragraph of the same provision. In weighing the interest of the German government in shaping its education policy against the EU educational objectives (of teacher mobility), the Court gave full preference to the latter.

Indeed, Member States are granted only a very limited amount of leeway in the implementation of their education policy whenever it touches upon internal market freedoms, which helps to explain the increasing criticism of politicians directed at the ECJ. The Belgian-Austrian Education Saga ${ }^{26}$ provides an interesting example in this context. Belgium and Austria are both relatively small countries with large neighbours in which the same or a similar language is spoken and both had a very open and unrestricted higher education access policy in comparison with those neighbouring countries. This situation led to a high influx of French and German students, especially in the area of medical studies, which they sought to restrict in order to prevent the overburdening of their education systems and to prevent a shortage of medical professionals in the long run, expecting the foreign students to return 'home' after their studies. The Court declared the legislation in question, limiting the access of foreign students to those who could prove that they were admitted to the same kind of study in their Home State, to be incompatible with EC law. The judgment caused considerable uproar in Austria and beyond, with Chancellor Wolfgang Schüssel expressing fierce criticism directed at the Court. According to the Chancellor, the Court should have borne in mind that education was a policy area reserved for the national government. ${ }^{27}$ He told the German newspaper Süddeutsche Zeitung:

in recent years [...] the ECJ has systematically expanded European competencies, even in areas where there is decidedly no Community law. Suddenly judgments emerge on the role of women in the German federal army, or on access of foreign students to Austrian colleges - that is clearly national law. ${ }^{28}$

He was supported by other politicians, such as the Danish Prime Minister Anders Fogh Rasmussen, who declared to Der Standard that:

\footnotetext{
26 Case C-65/03 Commission v Belgium [2004] ECR I-6427; Case C-147/03 Commission of the European Communities v Republic of Austria [2005] ECR I-5969. See Garben (n 14).

${ }_{27}$ G Parker, 'Austrian chancellor urges EU court to heed national feelings' Financial Times (London 20 April 2006).

28 Interview mit dem künftigen Ratspräsidenten der EU, ‘300 Sprachen und 500 Dialekte das ist mein Europa', Süddeutsche Zeitung (Munich 13 December 2005). See also P Belien, 'Austria and Denmark Fear American-Style Supreme Court' The Brussels Journal (13 January 2006).
} 
We all easily have the feeling that there [at the ECJ], decisions are being taken of which the basis of the judgments do not fully correspond with what we have agreed as the political basis of the development of the EU. ${ }^{29}$

Arguably, these political overstatements do not reflect an entirely correct analysis of European law, but it cannot be denied that the overall tone of art 165 TFEU is one demanding respect for national autonomy and diversity in educational affairs, which seems to be ignored by the Court. Responsibility and powers relating to the content and organisation of educational systems lie primarily with the Member States, leaving the EU with the secondary role of facilitating and encouraging cooperation and mobility. This is an important paradigm, and the argument that it should not be hollowed out by overly extensive interpretation of internal market powers and the rights that citizens derive from the fundamental freedoms, especially by a too rigid application of the proportionality test, is a fair one. Indeed, the impact of the Court's case law is substantial. In some instances, it puts the Member States to great expense and in other instances it curbs their policy discretion. Even more so considering the 'snowball' dynamics of European integration, which means that negative integration often needs to be accompanied by positive integration in the form of co-ordinating or harmonising legislation. When national legislation is condemned for incompatibility with European law, its inapplicability leaves a gap, triggering the need for a European solution. This raises the question about what should happen if there is no legislative competence in the field in question. According to Handoll:

one could indeed argue that, where the Court has recognised the intrusiveness of 'functional' rules of free movement and non-discrimination into areas of national competence, the Community will have to be competent to take positive action to resolve resulting difficulties. ${ }^{30}$

This feeds back into the first strand of the ECJ's judicial activity in education: strengthening the EU's competence so as to allow it to enact legislation in this area.

This is not to say that it is undesirable to encourage EU co-ordination of educational policies. In many cases, co-operation is the key to a host of problems. For example, one could argue that a European arrangement dealing with 'who pays what for mobile students' is necessary to solve the problem of potential double entitlements to study funding. In the Morgan and Bucher ${ }^{31}$ cases, dealing with the question of to what extent Member States should allow for the 'exportability' of maintenance

29 EUObserver.com at http://euobserver.com/9/20666 accessed on 30 November 2010.

30 Handoll (n 2) 36.

31 Joined Cases C-11/06 and C-12/06 Morgan and Bucher [2007] ECR I-9161. 
grants, Austria, Sweden, the UK and the European Commission argued that forcing Member States to award grants to resident students going abroad to study was undesirable considering the risk of duplication of entitlements, caused by the absence of co-ordinating provisions between the Member States in relation to student support. Indeed, it turned out that apart from the German funds she claimed, Ms Morgan received from the United Kingdom authorities financial support in the form of an allowance for tuition fees and maintenance costs, as well as a loan. Although EU law seems to favour a system in which the host state pays for the mobile student, a common system of exportability, cancelling this obligation of the host country, seems to find favour with several authoritative commentators. They argue that it is preferable to impose the burden of providing students with financial aid on the home state. ${ }^{32}$ The amount of financial support for studies abroad could be pegged to the amount for studies in the home state, making the exportation of student support 'financially neutral to the treasury, to the extent that the latter need not subsidise the more expensive tuition and subsistence costs potentially incurred in other Member States'. ${ }^{33}$ This approach would mimic that adopted in the area of health care, where the state is only obliged to compensate for treatment abroad up to the level of expenses that would be reimbursed for the same treatment at home. ${ }^{34}$ Van der Mei points out that it is in that home state that students or their parents have paid taxes, thereby contributing to the financing of education and grant schemes, and it is that state which will benefit from the acquired skills and knowledge of the students. ${ }^{35}$

At the end of the day, the decision whether to have the host states provide funding to the guest student on an equal basis to nationals or to have home states pay for their mobile nationals is a policy choice that, within an EU context, the European legislature should make. Although Member States might not be keen on seeking a solution within the EU framework, ever suspicious of a Commission power-grab in educational affairs, this is one of the areas where such co-operation might really pay off. However, not in all situations is harmonisation a desirable answer.

\footnotetext{
32 A Van Der Mei, 'Freedom of Movement for Students: In Search of a More Satisfactory Balance between the Goal to Promote Student Mobility and the Need to Protect Education Systems' in H Schneider (ed), Migration, Integration and Citizenship: A Challenge for Europe's Future, vol I (Forum Maastricht, Maastricht 2005). G Davies, 'The Process and Side-Effects of Harmonisation of European Welfare States (2006) Jean Monnet Working Paper 02/06, 24-25. See also G Davies, 'Higher Education, Equal Access, and Residence Conditions: Does EU Law Allow Member States to Charge Higher Fees to Students not Previously Resident?' (2005) 12 Maastricht Journal of European and Comparative Law 227, and G Davies, 'Any Place I Hang my Hat, or: Residence is the New Nationality' (2005) 11 (1) European Law Journal 43.

${ }_{33}$ Dougan (n 6).

34 Van Der Mei (n 32).

35 Van Der Mei (n 32).
} 
When Advocate General Sharpston in her Opinion in the Bressol case, which concerns the claim of French students against the newly imposed Belgian legislation restricting migrant students access to certain studies, argued that the Belgian legislation dealing with its universities overburdened by French students was in breach of EU law, she might have been too quick to brush away Belgium's problems by presenting harmonisation as the solution. ${ }^{36}$ After rejecting all the justifications brought forward by the Belgian Government, she invited the European legislature to start to consider its legislative options on the matter. Although it triggers an interesting debate on the scope of EU competence in the area of higher education, to present harmonisation as the solution in this particular case not only testifies to a certain amount of insensitivity, but it also fails to offer a really viable alternative. What kind of measure would deal with the French/Belgian and German/Austrian problems in a satisfactory manner: harmonisation of entry requirements for certain studies all over Europe? What would be the content of those requirements? A European-level imposed numerus clausus system for selected studies? Or a European-level imposed 'free access without charge' regime? Although it is perhaps not impossible to find some kind of acceptable system, the fact that Member States would be forced to accept such as the only solution severely impinges on their freedom to organise higher education in the way they see fit. ${ }^{37}$

\section{Member States Europeanising higher education: Bologna and Lisbon}

Notwithstanding the legitimate criticism of the ECJ's somewhat intrusive approach, it should be accepted that European law sometimes affects national policy, including education policy, in a way not planned by the national legislature. The EU has been endowed with functional powers, which are necessary in the creation of an internal market. It is neither realistic nor constructive to argue that certain policy areas should be removed from the scope of potential EU influence, since the (exercise of the) functional powers will by nature cut horizontally across all policy fields, at least to a certain extent. Moreover, the wailing cries of the politicians are often more crocodile tears than anything else. Obviously it is not just the ECJ that is responsible for all the educational integration of the past years. It is the Member States themselves that have played the most important role in the increased Europeanisation of education, both in and outside their Council capacity, in recent years most notably in the intergovernmental arena of the Bologna Process. To be regarded as

\footnotetext{
36 Opinion of Advocate General Sharpston delivered on 25 June 2009 in Case C-73/08 Nicolas Bressol and Others and Céline Chaverot and Others $v$ Gouvernement de la Communauté française.

37 See Garben (n 14) 1505.
} 
both the product and the continuation of a series of European conferences and a certain number of policy decisions, ${ }^{38}$ the Bologna Process has as its aim the creation of a so-called European Higher Education Area by 2010. To this end, the signatories have agreed to reform their higher education systems so as to bring them in line with each other, in other words to harmonise them. The core feature of the Bologna Process is the introduction of a common Bachelor-Master-Doctorate system. This revolutionary enterprise was set in motion quite suddenly. It was initiated in 1998, when at an international Forum organised in connection with the celebration of the $800^{\text {th }}$ anniversary of the Sorbonne University, the Ministers of Education of France, Germany, Italy and the United Kingdom decided on a 'Joint Declaration on harmonisation of the architecture of the European higher education system'. It was open for the other Member States of the European Union (EU), as well as for third countries, to join. The Italian Minister for Education extended an invitation to fellow Ministers in other European countries to a follow-up conference, which was to take place in Bologna the following year. ${ }^{39}$ This conference indeed took place, in June 1999, and it was on this occasion that no fewer than 29 European countries agreed on a Declaration that would fundamentally influence the future of their higher education systems. ${ }^{40}$

Reading the actual text of the Bologna Declaration, one cannot but be struck by the ambitious language it employs. The Declaration commences with the statement that: "the European process, thanks to the extraordinary achievements of the last few years, has become an increasingly concrete and relevant reality for the Union and its citizens' and continues to say that:

we are witnessing a growing awareness in large parts of the political and academic world and in public opinion of the need to establish a more complete and far-reaching Europe, in particular building upon and strengthening its intellectual, cultural social and scientific and technological dimensions.

It seems difficult to imagine that these phrases stem from the same countries that have been keen on keeping higher education safely in the hands of the nation state. Furthermore, the meaning of these phrases becomes quite ambiguous upon realising that the Bologna enterprise is taking place outside the framework of the EU. While in words praising the achievements of the EU in the process of European integration and

\footnotetext{
38 Eurydice (2003) 'Focus on the Structure of Higher Education in Europe. National Trends in the Bologna Process 2003/04'.

39 E Hackl, 'Towards a European Area of Higher Education: Change and Convergence in European Higher Education' (2001) EUI Working Paper RSC No 2001/09 21.

40 This is known as the 'Bologna Declaration'. Currently 46 countries take part in the process.
} 
explicitly referring to the 'Union and its citizens' and the aim of 'consolidating European citizenship', the Declaration is in fact nothing more than a soft-law instrument which envisages practically no involvement of the EU. Its intergovernmental character, in addition to its extended membership that currently enables 20 non-Member States to take part, places the Bologna Process outside the EU's formal policy-making process. ${ }^{41}$ Hackl points out that the developments concerning the Bologna Process seem to contradict the 'traditional resistance of the EU Member States to any harmonisation policy in education and to increased Community competences'. ${ }^{42}$ It is true that the pro-European integration wording and tone of the Bologna Declaration are in that respect remarkable. However, the fact that the Member States decided to tackle higher education issues in an intergovernmental manner actually illustrates their resistance to EU involvement and their desire to remain fully sovereign.

The tense relationship between the EU and the Bologna Process notwithstanding, the latter constitutes a catalyst for the promotion of student mobility and increased involvement in higher education not only outside but also within an EU context. Firstly, it is likely to strengthen the Court in its pro-student mobility approach. In Advocate General Sharpston's opinion to the follow-up Belgian Education Case, mentioned above, the Bologna Process was indeed used to help set the scene for her progressive opinion. ${ }^{43}$ Advocate General Ruiz-Jarabo Colomer also invoked the Bologna Process in order to build up his argument for increased student mobility in his opinion to the Morgan and Bucher cases. ${ }^{44}$ Furthermore, Bologna has allowed the Commission to gain influence within an EU context, mainly by - in reaction to the Bologna Process - developing 'its higher education discourse as a key for the Europe of knowledge'. ${ }^{45}$ The Commission has been able to do this because many of the ideas of the Bologna Process have found clear correspondence with European Council documents, most importantly the Lisbon Council Conclusions, and consequently it has seen its political mandate in the higher education sector expanded. According to Keeling, 'the Commission's dynamic association of the Bologna university reforms with its Lisbon research agenda and its successful appropriation of these as European-level issues have placed its perspectives firmly at the heart of higher education policy de-

\footnotetext{
${ }^{41}$ R Keeling, 'The Bologna Process and the Lisbon Research Agenda: The European Commission's Expanding Role in Higher Education Discourse (2006) 41 (2) European Journal of Education 207.

42 Hackl (n 39) 2.

43 Opinion of Advocate General Sharpston (n 36) para 1.

44 Opinion of Advocate General Ruiz-Jarabo Colomer, Morgan and Bucher (n 31) paras 45-46.

45 P Ravinet, 'From Voluntary Participation to Monitored Coordination: Why European Countries Feel Increasingly Bound by their Commitment to the Bologna Process, (2008) 43

(3) European Journal of Education 357.
} 
bates in Europe'. ${ }^{46}$ The Lisbon European Council was not a one-off event, and the goal to become a European knowledge economy has been firmly placed on the European agenda ever since. Two years after the Lisbon Council, in Barcelona, the European Council made even clearer reference to the emerging common area of higher education, calling for further action to introduce instruments to ensure the transparency of diplomas and qualifications (ECTS, diploma and certificate supplements, European $\mathrm{Cv}$ ) and closer co-operation with regard to university degrees'. ${ }^{47}$

The most obvious example of this increased mandate of the Commission to act within the EU framework is the introduction by the Lisbon Strategy of the Open Method of Coordination (OMC) in education. The Commission plays a central role in the $\mathrm{OMC}$, and is now in a position to set overarching goals for the European higher education sector. These are not legally binding, but it does boost the Commission's political power in this field. The Commission can influence the direction in which the European higher education sector(s) will develop and evolve, and that is quite a powerful position in a policy area where the Member States had always been particularly suspicious of the Commission and have done their utmost to tie the Commission's hands. Nevertheless, although it is true that the Commission has thus been able to affirm its role in higher education matters within the EU context as a consequence of the Lisbon Strategy, and has used the increased interest in achieving a knowledge economy to advocate its aims and programmes in higher education, it seems that this is more a natural consequence of the momentum behind both the Bologna Process and the Lisbon Strategy than deliberate tactics of the Commission. It was the European Council that shortly after the Bologna Declaration lifted the latter's overarching philosophy to a higher level, in making it part of Europe's most important strategic objective. As Kahn put it:

two years before the European Council of Lisbon, the Sorbonne and Bologna Declarations foreshadowed the EU's well known 'strategic goal for the next decade: to become the most competitive and dynamic knowledge-based economy in the world'. ${ }^{48}$

The fact that the Member States allow the Commission to take this front seat can probably be explained by the explicitly intergovernmental, flexible and 'soft' nature of this co-operation. Arguably, the Member States feel safe enough seeing that their participation is entirely voluntary and

\footnotetext{
46 Keeling (n 41) 203.

47 See P Zgaga, 'The Bologna Process: From Prague to Berlin and After' (paper on the basis of author's engagement in the Bologna follow-up group as rapporteur for the Berlin conference in September 2003).

48 S Kahn, 'The European Higher Education Area at the Crossroads' (2002) 2 Revue en ligne 'Etudes Européennes' < http://www.etudes-europeennes.fr> accessed in 2009.
} 
that, as such, they have ultimate leverage over the Commission if it decides to take matters in an unwanted direction. Furthermore, it is probably not inconvenient to the Member States either to have an expert and well-equipped organiser at the table, who can incidentally also function as a 'scapegoat' or 'lightning conductor' if the formulated policies prove unpopular in the national arena.

The momentum of which the Lisbon Strategy within the EU and the ever-developing Bologna Process outside the EU are part causes them to increasingly converge. Considering that many of the goals and ideas expressed in the context of the Lisbon Strategy concur with the overarching philosophy, as well as with the concrete aims of the Bologna Process, this convergence is not surprising. The OMC plays a key role in this merging 'into one policy framework'. ${ }^{49}$ Most of the elements or characteristics of the $\mathrm{OMC}$, eg setting timetables, establishing indicators and benchmarks and operating accordingly, setting specific targets and periodic monitoring, evaluation and peer review, can now also be found in the activities around the Bologna Process. Some even claim that the Bologna Process is now considered to be part of the Open Method of Coordination. ${ }^{50}$ Since Berlin 2003, the Commission co-ordinates monthly 'Bologna seminars', which seek to push forward the spread of best practice through the OMC. ${ }^{51}$ The European Network of Quality Assurance Agencies (ENQAA) plays an important role in the implementation of the Bologna Declaration. As Furlong notes, the ENQAA is a typical OMC institution in its structure and operations, set up and supported by the European Commission. In Berlin, this institution was mandated to develop standards, procedures and guidelines on quality assurance. Bologna has, however, up until now, not been formally incorporated in the EU framework. Therefore, it cannot be called a part of the OMC, or the Lisbon Process, as such. Rather, it is seen that the activities of the Commission in the framework of Bologna are considered to be part of the OMC, or the Lisbon Process. The Commission itself formulates it as follows:

The Lisbon Strategy encompasses the Commission's contribution to the intergovernmental Bologna Process, aiming to establish a European Higher Education Area by 2010, mainly in the areas of curricular reform and quality assurance. The Bologna process coincides with Commission policy in higher education supported through European programmes and notably Socrates-Erasmus, Tempus and Erasmus Mundus. The Commission stimulates Bologna initiatives

\footnotetext{
49 J Huisman \& M van de Wende, The EU and Bologna: Are Supra- and International Initiatives Threatening Domestic Agendas? (2004) 39 (3) European Journal of Education 34-35.

50 Lonbay (n 6) 253.

51 P Furlong, 'British Higher Education and the Bologna Process: An Interim Assessment' (2005) 25 (1) Politics 55.
} 
at European level and participates as a full member in the Bologna Follow-up Group and the Bologna Board.

The focus of much of the research in this area is on the European Commission as a policy actor in the higher education sector, which is understandable because of its importance as well as its fascinatingly difficult position. But it should not be forgotten that the EU Member States are the main driving forces behind the reform movement sweeping European higher education, in their capacity as the Council and in Bologna's intergovernmental arena. The states seem keen to pursue the related objectives in several political contexts, both inside and outside the EU. It is not entirely clear why, and whether, they would be in favour of increased convergence. It is most likely that, if given the choice, they would prefer to keep Bologna separate from the EU framework. But at the same time they do benefit from an increased convergence, or rather profusion, of Bologna and the Lisbon Strategy. Apart from the objective aims to achieve in European higher education, the national political actors are suspected of having embarked on the Bologna Process for more subjective reasons. Many political scientists have reported on the 'two-level game' that was played by the main political actors of Bologna. ${ }^{52}$ As argued by Moravcsik, international co-operation redistributes domestic power in favour of national executives by permitting them to loosen domestic constraints imposed by legislatures, interest groups, and other societal actors. ${ }^{53}$ The Bologna Process has been described as a 'red herring', which the national governments use for their own domestic purposes. ${ }^{54}$ Kahn notes:

it is a highly convenient pretext for nations to evade the responsibility for structural reforms, always necessary and suddenly indispensable because of an abstract and disembodied European constraint. If they cannot lay the blame for the constraint on some little 'bureau' in Brussels or elsewhere - there isn't one - they can always plead the fulfilment of undertakings to their partners: they must follow their partners' example or will lose ground.

Perhaps the Member States even created, or conveniently did not resolve, the mistake that the Bologna Process was imposed by 'Europe', taken to mean the EU. In this line, Ravinet argues that the governmental players 'manipulate the objectives and use them as leverage and justification for reforms, even though they are not unilaterally obliged to implement these objectives'. She explains:

\footnotetext{
52 See, most notably, C Racké, The Emergence of the Bologna Process: Pan-European instead of EU Governance' in D de Bièvre \& C Neuhold (eds), The Dynamics of Changing Modes of Governance in Europe,(Edward Elgar Publishing, Cheltenham 2007) and P. Ravinet (n 45). 53 A Moravcsik, 'Why the European Union Strengthens the State: Domestic Politics and International Cooperation' (1994) Centre for European Studies Working Paper Series no 52, Harvard University 1.

54 Kahn (n 48) 4.
} 
The Bologna Process seems to have an element of juridicity (Pitseys 2004), in that it appears to be legally binding in nature, especially when participating countries misinterpret their commitments as requiring conformity to superior and legally binding European policies. This lack of clarity can be used as a means to legitimise national reforms. This misconception is reinforced when Bologna declarations and communiqués are presented as texts of quasi-legal value, even though initially the Bologna Process did not have any official legal status. ${ }^{55}$

In addition, several authors also argue that the use of the knowledge-economy rhetoric has contributed to the increasing sense of 'being bound' to the Bologna objectives by the signatories themselves. Ravinet argues convincingly that the overlap between the Bologna objectives and those of the EC is, to a certain extent, "where they derive their authority and importance from, at least partly explaining why their use contributes so much to a sense of bindingness'. ${ }^{56}$ Fejes concurs, stating that:

planetspeak rhetoric such as the ideas of the knowledge society, employability, lifelong learning, quality assurance and mobility [...] constitute a way of thinking that makes participation in the Bologna process and the implementation of its objectives a rational way to act. ${ }^{57}$

In that sense, one can say that the Process has begun to lead its own life, once the 'soft' and flexible product of informal intergovernmental cooperation, now turning into something that 'needs to be done' without anyone knowing exactly why, or having different reasons to think so. This partly explains the surprising force of this voluntary project of policy convergence. All the actors appear to have their own objectives, which can be located in some common rhetoric and therewith a powerful platform for action is created. As Corbett puts it:

governments want to use Europe to introduce domestic reform. The Commission wishes to extend its competence in higher education. University presidents want recognition. They each bring elements of the solution, as embodied in Bologna. ${ }^{58}$

A critical attitude is warranted here. If European-level action is resorted to in order to avoid national public scrutiny, severe problems with the democratic legitimacy of the project arise. Such concerns have pla-

\footnotetext{
55 Ravinet (n 45) 353.

56 Ravinet (n 45) 357.

57 A Fejes, 'The Bologna Process: Governing Higher Education in Europe through Standardization' (paper presented at the third conference on Knowledge and Politics - the Bologna Process and the Shaping of the Future Knowledge Societies, 2005) 219.

58 A Corbett, 'Europeanisation and the Bologna Process: A Preliminary to a British Study (paper presented to the one day conference co-sponsored by the ESRC and UACES, 2004) 12.
} 
gued the EU for a long time, and to a certain extent rightly so. The question of whether the EU should possess, exercise and seek to expand its powers in higher education is an important one, and its answer closely relates to these legitimacy questions. But instead of this being a valid argument for the governments of the Member States to embark on the Bologna Process without and outside the EU institutions, it is an argument why it is even more worrisome that they have done so. The EU, for all its democratic defects, is still more democratic than the intergovernmental smoke-filled rooms in which the Sorbonne and Bologna Declarations came into existence. The Sorbonne Declaration, where the essential ideas were born and introduced, was the product of the birthday party of a prestigious university celebrated by a select group of ministers among themselves. The subsequent Bologna Declaration was signed at an elite party, as an intergovernmental piece of soft law but with far-reaching ambitions, without any recourse to the institutional framework of the EU, thereby avoiding its built-in safeguards, checks and balances. There was hardly any parliamentary involvement, barely any public consultation, and most reforms were rushed through in only a few years. Although the governments proudly speak of the bottom-up approach of the Bologna Process, meaning that the state is in full control as opposed to supranational rule-making, many opine that the changes of the Bologna Process were imposed on the actors in the field in a top-down manner with little or no opportunity of debate. ${ }^{59}$

Indeed, this is one of the reasons why it has been argued that the Bologna Process, if deemed necessary for the future of European higher education, should have been created within an EU context, preferably in the form of a Bologna Directive. ${ }^{60}$ This argument, however, is only really forceful if one contrasts the Bologna Process with EU hard law, adopted through the Community method. It is, in fact, only in that case that it can convincingly be claimed that the decision-making mechanisms guarantee a certain level of democracy and legitimacy and that the rule of law is upheld, not least by the fact that individuals, such as students, have recourse to the European Court. The ever-increasing powers of the European Parliament should compensate for the loss of parliamentary control at the national level, a loss that is partly inherent in international law/policy making. From this point of view, therefore, the increasing use of soft law in the EU, such as the OMC, can be considered as worrisome as the public international soft law making of the Bologna Process outside the EU's institutional framework. As Trubek, Cottrell and Nance note, recent years have indeed seen significant criticism on the use of soft law in the EU, the objections including that soft law lacks the clarity and

\footnotetext{
59 Lonbay (n 6) 253.

60 See S Garben, 'The Bologna Process: From a European Law Perspective' (2010) 16 (2) European Law Journal 186-210.
} 
precision needed to provide predictability and a reliable framework for action and that it by-passes normal systems of accountability. ${ }^{61}$ Although soft law appears to be less intrusive to national autonomy, and thus more respectful of national preferences and diversity, it, in fact, proves to be a treacherously powerful policy source. More than being a relatively unchecked and unlimited method of policy making, its power actually lies in the fact that it is unchecked and unlimited. This is an important finding, for it lays bare its doubtful legitimacy, as well as the underlying problem that apparently what politicians strive to achieve does not concur with what their constituencies believe. This gap between citizens and their governors has often been discussed both in an EU and national context. The debacle of the European Constitution is an obvious point of reference in this regard.

\section{Europeanisation equals economisation?}

The undemocratic nature of the education reforms of the past decade finds illustration in the persistent protests and demonstrations taking place all over Europe. Students and teachers, the intended beneficiaries of increased intra-European mobility, seem to have turned en masse against the recent surge of Europeanisation of higher education. ${ }^{62}$ Although

61 D Trubek, P Cottrell \& M Nance, “Soft Law", "Hard Law" and EU Integration' in G de Burca \& J Scott (eds), Law and New Governance in the EU and the US (Hart Publishing, Oxford 2006) 66.

62 In 2005, French students protested against the Bologna reforms, causing the University of Paris 8 Vincennes-Saint-Denis to temporarily shut its doors. See Jane Marshall Paris, 'French protest over Bologna' Times Higher Education (29 April 2005). In 2006, Swedish students protested against the proposal to cut PhD terms. See C Schubert, 'Swedish students protest proposal to cut PhD terms' (2006) 12 Nature Medicine 373. In 2008, numerous protests directed specifically at the Bologna Process, as well as the 'commercialisation of higher education' in general took place all over Europe, but mostly in Spain. On 7 May 2008, close to 5,000 students protested against the Bologna Process in Zagreb. On 19 June student representatives in Austria protested against further restrictions to take a master's degree, part of the reforms introduced by the Austrian government in relation to the Bologna Process. On 8 May, more than 10,000 students and teachers protested against the Bologna Process in Barcelona, after they had already done so in a huge demonstration with 10,000 participants in Barcelona and more than 3,000 in Sevilla on 6 March 2008. In Grenada, 150 protesting students occupied a faculty on 24 April. Protests also took place in Madrid where students blocked roads. On 22 October protests took place in 30 cities across Spain against the Bologna Process and in defence of public education. Protests were staged in Italy, where about 5,000 people assembled in Milan. Less than a month later, on 20 November, thousands of students in several Spanish cities protested again against the Bologna Process. For an overview of all the protests that took place in 2008, see <http:// fading-hope.blog-city.com/students_protest_worldwide_against_commercialisation_bologn. $h t m>$ accessed on 30 November 2010. In 2009, the Spanish resistance continued. On 19 March, students occupied the central building of the University of Barcelona in protest against Bologna, and teachers, parents, students, pupils and workers joined a demonstration involving 50,000 participants in the city centre demanding different education policies. On 10 February 2009, professors and researchers in France joined the protest against the Bologna reforms in the nation's major cities. See M Garcia Gomez, 'Education: Bologna 
the protesting crowds are perhaps not always consistent in what they are protesting against, for sometimes it is the EU, sometimes the Bologna Process, and sometimes their national government, it might be possible to distil a common objection against many of the reforms that the education sectors of the Member States have seen over the past years. The general sense seems to be that despite all the political high talk about how imperative education is for contemporary societies, the sector and its people are continuously subjected to cutbacks and downsizings, and increasing demands for economic efficiency. In that sense, it is probably more the economisation than the Europeanisation of higher education that is objected to, but there is some truth in conflating the two. The Bologna Process carries a distinct economic flavour, as does the education policy of the EU. The former introduces the Anglo-Saxon model on the European continent, not only in terms of labels and structures, but arguably also in ideology. The latter has most often dealt with education from an economic perspective, and has most recently brought it into the Lisbon Strategy where Europe is to become the world's most competitive knowledge economy, and the educational rights that have been granted seem to flow more from a labour market logic than anything else. This is a valid objection against increased EU involvement in education, as well as against the Bologna Process. As Karlsen argues:

The Bologna main objects 'The European Education Area' correspond well to the 'Internal Market'. In particular higher education and knowledge are looked upon and treated more like economic commodities inside a certain area. There is clearly a movement towards a marketization in the field of education (Schostak 1993). The dominant aims for the exchange and mobility of 'human capital' and knowledge are preparations for increasing competition on the global market place and preparation of students for the internationalized labour market. The cultivation of the individual (Bildung) is not absent, but primarily instrumental and not for its intrinsic values. ${ }^{63}$

Indeed, apart from the politically strategic aims that we have discussed above, the main reasons to embark on the structural harmonisation of the European higher education systems through the Bologna Process

process, sales time in French universities' <http://www.cafebabel.co.uk/article/28859/ bologna-process-education-protests-clermont.html> accessed on 30 November 2010. In July 2009, Cologne students expressed their criticisms of the Bologna Process. See J Fallon, 'Köln gegen Bologna: die deutschen Studenten formieren sich', <http:/ / www.cafebabel. de/video/183/koeln-gegen-bologna-studenten-proteste-deutschland.html> accessed on 30 November 2010. In October 2009, the city of Vienna witnessed massive protests against the Bologna reforms. See B Lang, 'Studierendenproteste in Wien: Bologna stinkt!' <http:// www.cafebabel.de/article/33754/studierendenproteste-in-wien-die-groe-ruhe-n.html> accessed on 30 November 2010.

${ }^{63}$ G Karlsen, 'The Bologna Process: A Judicial Confirmation of EU's Policy of Education?' (paper for the $3^{\text {rd }}$ Conference of Knowledge and Politics at the University of Bergen 2005) 4. 
was to increase the competitiveness of Europe on an international scale. And the main purpose of the OMC in education is to fully exploit its potential in the creation of a European knowledge based economy. More and more, the purpose of education in contemporary society is being phrased as an almost exclusively economic one. The economic benefits for both the individual and society at large are constantly stressed and argued as reasons for increased European-level co-operation. Although it is true that education is key to economic development and that potentially large gains are to be made by engaging in European-level co-operation in this area, it does reflect a dangerously one-sided perspective on education. One of the possible consequences of this development is that courses are increasingly designed to suit the needs of the market, rather than to instil students with knowledge for the sake of individual and academic progress. This means that the content of university studies might become tailored to the needs of prospective employers, who demand graduates that are fully operational from day one, turning university education into vocational training. This development might equally threaten the existence of less economically viable disciplines such as history, archaeology and philosophy to the benefit of law, economics and business studies. In addition, the Bologna Process, but also the European Commission, encourages the 'autonomy' of higher education institutions vis-à-vis their national governments. To a certain extent, this seems to explain the surprisingly supportive attitude of higher education institutions towards the Bologna reforms. Autonomy could indeed be deemed desirable from an academic perspective, but its potential economic implications should not be underestimated. It might mean less 'meddling' from the government, but that usually also comes at the price of less government funding. This implies increased reliance on funding from other sources, such as the private sector, and although that might seem desirable from the viewpoint of saving public funds, it does raise concerns about the independence and objectivity of research and education.

It is in the first place the Member States who prove so keen to 'economise' higher education. They promote this approach in their capacity as Member States of the EU, most particularly via the Council and its Lisbon Strategy, and they do so outside the EU framework, most notably in the context of the Bologna Process. Nevertheless, the EU institutions also play their part. The European Commission seems so keen to fully exploit the responsibility and power that it has finally acquired in this field that it does not question the Member States in their policy decisions. It has never really objected to the undemocratic nature of the Bologna Process or the education $\mathrm{OMC}$, and it faithfully plays its part in promoting closer ties between business and education, in promoting autonomy for higher education institutions and in arguing for efficiency and target-setting in education. Furthermore, the European Court almost limitlessly applies 
the internal market freedoms to educational actors and their activities. This not only poses a legal problem in bypassing art 165(1) TFEU, but it also simply does not seem to respect the fact that, in education, considerations that are not economic - and that might very well be at odds with economic efficiency - play an important role. Obviously, the European Court has applied a more nuanced approach, allowing restrictions of movement if objectively justified. But the national policies in question have to meet a rigorous and strictly applied proportionality test if they even only indirectly hinder a free single market. It is understandable that some, on principle, object to internal market logic being the general rule, with aims such as achieving a high quality of education being the exception.

So, although it is the Member States who drive this process of economisation much more than the European Court, the latter should, nevertheless, think over its approach. From the foregoing perspective, European citizenship, laid down in art $21 \mathrm{TFEU}$ (ex art $18 \mathrm{EC}$ ), might be a better basis for the development of equal treatment rights for students than the four freedoms are. In this sense, it is worrying that the ECJ has confirmed that education can be qualified as a service. The next step could very well be to qualify students as recipients of those services. Recently, Advocate General Ruiz-Jarabo Colomer in his Opinion in Morgan and Bucher indeed argued in favour of this interpretation of the service provisions. He argued that:

obstacles to attending classes outside the country of origin, as well as limiting the range of options available to the students, have an effect on the educational establishment, by reducing their opportunities for attracting foreign students.

He went on to draw the expected analogy with health care, arguing that the Court had already held that

the freedom to provide services includes the freedom for the recipients of services, including persons in need of medical treatment, to go to another Member State in order to receive those services there, and also paid medical care

and that this reasoning had to be extended to the realm of higher education. He stated that universities normally offer education in exchange for remuneration, in terms of registration charges or monthly instalments, so any obstacle to attending their classes had to be regarded as a restriction on the freedom to provide services.

The Opinion of the Advocate General was delivered in March 2007, and although the Court in its Morgan and Bucher judgment did not touch the issue, it implicitly gave a tentative answer in the Schwarz judgment 
of September 2007. The Schwarz case concerned the refusal to grant tax relief on the ground that the private school in question was established in another Member State. The Court held that the German legislation impeded the possibility of taking advantage of offers of education emanating from such a school, meaning that its freedom to provide services was impaired. It was, according to the ECJ, settled case law that 'the freedom to provide services includes the freedom of the persons for whom the services are intended to go to another Member State, where the provider is, in order to enjoy the services there'. ${ }^{64}$ With the Schwarz judgment, the Court has already begun to transpose its approach in medical services to the area of education, and there is no particular reason to assume that the Court would not hold this reasoning to be applicable in the case of migrant students. Art 56 TFEU (ex art 49 EC) will then be the default basis upon which student claims are dealt with, as it takes precedence over art 21 TFEU. ${ }^{65}$ If the Court decides to go this way, it will probably have the effect of strengthening student claims to equal treatment, including maintenance grants, should the establishment in question operate as a private school. But, as Dougan has pointed out, this would

have the effect of diverting Member State resources away from financial support for public sector education (within the domestic territory) towards private sector establishments (in other countries) - amounting in effect to a form of Community-led contracting outcum-outsourcing. ${ }^{66}$

This is certainly something for the Court to think about.

\section{Conclusion}

As we have discussed above, dealing with education matters with a fundamentally economically tainted view is not without consequence. Although there might be legitimate reasons to choose this approach, the point is that there should be an open discussion about this with the public at large. Perhaps there is majority support for taking higher education in this direction, but it could also very well be that there is not. In this sense, it could be considered suspicious that the two developments that are responsible for most of the recent economisation of higher education over the past decades, to wit the Bologna Process and the Lisbon Strategy, are both fundamentally undemocratic and unaccountable. Indeed, it would have been better to act within the EU legislative framework in-

\footnotetext{
${ }^{64}$ Joined Cases 286/82 and 26/83 Luisi and Carbone [1984] ECR 377, paras 10 and 16, as cited by the ECJ in Case C-76/05 Schwarz and Gootjes-Schwarz v Finanzamt Bergisch Gladbach [2007] ECR I-6849, para 36.

65 Case C-92/01, Stylianakis [2003] ECR I-1291, para 18.

66 Dougan (n 6) 979.
} 
stead, especially with regard to the Bologna Process. If anything, such a move would have triggered a Europe-wide debate about higher education and its purpose in European societies. The Commission could have taken its time to gather the necessary knowledge about Europe's higher education systems and to gather the views of the stakeholders and the general public. Not unimportantly, this course of action would have allowed the European Parliament to weigh in on the matter. It is indeed questionable whether in this scenario the Bologna Process, with its current content, would have come into existence at all. But rather than this constituting a good reason for the EU legislative framework to have been avoided, it seems that this put a finger right on Bologna's unforgivable flaw: its undemocratic nature. To the extent that it pushes the commercialisation of higher education, it does so through the back door.

Although "the weight of Europe" ${ }^{67}$ is deployed to push reforms in this direction, it is not Europe or Europeanisation per se that forces a neo-liberal view on education affairs. It is also quite possible to aspire to a strong and unified Europe, without borders for educational mobility and with an active role in education policy, for non-economic reasons. Knowledge dissemination, cultural exchange, bundling of intellectual forces, achieving a better allocation of intellectual resources, creating centres of excellence, honouring Europe's intellectual heritage and many other reasons could support the case for a strong Europe in (higher) education affairs, without making this entirely contingent on an economic dimension. In fact, there can be fruitful interaction between the economic and the social goals. From this point of view, it is rather unfortunate that there is not a stronger legal basis for the development of a true European education policy. The absence of fully-fledged EU competence in this field compels EU institutions to approach education more indirectly and narrowly, via the internal market. Although it would therefore be desirable to amend art 165 TFEU, it is highly doubtful that the Member States would ever support such a development. On the record, they might argue that doing so would impinge too much on their educational autonomy, thereby playing on the fears that the EU is out to Europeanise (and commercialise) higher education. Off the record, it seems that they do not object to the Europeanisation (and commercialisation) of higher education, but that they object to doing so by more accountable and democratic means.

67 H Davies, 'Higher Education in the Internal Market' (2004) UACES European Studies Online Essays No. 3 <www.Uaces.org> 6 accessed in 2007. 